\title{
70 років Михаилу Романовичу Козаченку!
}

\author{
І. А. Панченко, кандидат сільськогосподарських наук , провідний науковий співробітник \\ лабораторії якості зерна
} Інститут рослинництва ім.. В. Я. Юр'єва УААН

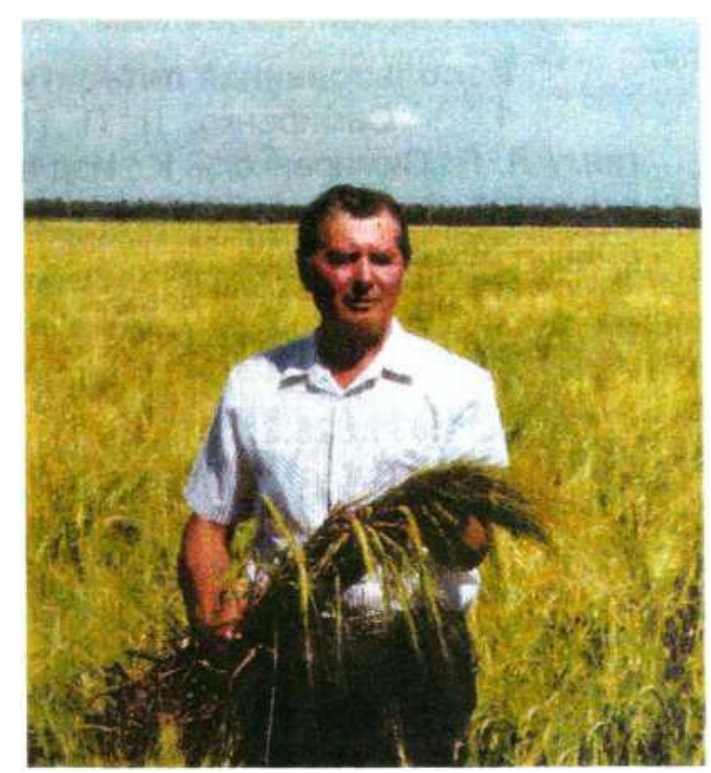

Козаченко М. Р. - видатний учений селекціонер-ганетик, доктор сільськогосподарських наук, головний науковий співробітник лабораторії селекції і генетики ячменю Інституту рослинництва ім. В. Я. Юр'єва Української академії аграрних наук (УААН), широко відомий в Україні, СНД і за їхніми межами.

Михайло Романович Козаченко у 1961 р. закінчив Дніпропетровський сільськогосподарський інститут за фрахом агрономія і кваліфікацією учений-агроном.

у 1961-1965 рр. - молодший науковий співробітник відділу селекції i насінництва Генічеської дослідної станції Всесоюзного науково-дослідного інституту кукурудзи ВАСГНІЛ (тепер Інститут зернового господарства УААН).

З 1965 р. весь плідний творчий шлях Козаченка М. Р. у науці пов'язаний 3 Інститутом рослинництва ім. В. Я. Юр'єва (в минулому Українським науково- дослідним інститутом рослинництва, селекції і генетики). У 1965-1968 рр. - аспірант інституту, з 1968 р. - молодший науковий співробітник, з 1971 р. - старший науковий співробітник, з 2002 р. - завідувач, з 2005 р. головний науковий співробітник лабораторії селекції і генетики ячменю.

Кандидатську дисертацію „Радіочутливість й індукована гамма-опроміненням мутаційна мінливість гібридів і сортів ячменю" захистив у 1970 р. 3 присудженням ученого ступеня кандидата біологічних наук.

У 1974 р. одержав учене звання старшого наукового співробітника.

М. Р. Козаченко $є$ одним з провідних учених в мутаційній і комбінаційній селекції та генетиці ярого ячменю. Він отримав нові науково обґрунтовані результати, які в сукупності розв'язують важливу наукову проблему і ґрунтуються на розроблених ним способах підвищення ефрективності методів експериментального мутагенезу, комбінаційної та мутаційної селекції, а також на комплексній мутаційно-комбінаційній технології селекційного процесу.

Ученим вирішені теоретичні і практичні проблеми підвищення результативності мутаційної селекції при взаємодії різних фракторів. Обґрунтовано використання ефективних критеріїв мутабільності. Встановлено оптимальні варіанти індукування мутацій в залежності від взаємодії відносної специфрічності мутагенів, їхніх доз і генотипів. Розроблено і вдосконалено способи й оптимальні варіанти нададитивного підвищення ефрективності методів хімічного і радіаційного мутагенезу при використанні вакуум-інфрільтрації нових хімічних модифікаторів, а також фрізичних і генетичних фракторів. Встановлено можливості і переваги різних методів використання мутацій та генетичного різноманіття різновидностей у практичній селекції, а також досліджено найефективніші 3 них при створенні практично цінних сортів ярого ячменю, зокрема, пряме індукування і повторний мутагенез у поєднанні 3 модифікацією його, а також прості і діалельні схрещування з оптимальним підбором вихідних різновидностних форм.

Ним обґрунтовано і вдосконалено ефективну комплексну мутаційнокомбінаційну технологію поєднання в мутаційно-селекційному процесі вдоскона 
лених методів експериментального мутагенезу та гібридизації.

Відтак, Михайло Романович зробив вагомий внесок у науку, зокрема в мутагенез і селекцію ярого ячменю, а також у сільське господарство України і СНД. Ним підвищено результативність методів хімічного і радіаційного мутагенезу в селекції ярого ячменю. Скорочено селекційний процес використання мутаційної мінливості і підвищено результативність селекції при використанні мутаційно-комбінаційної технології іï із застосуванням розроблених способів модифікаційного мутагенезу. Досліджено генетико-еволюційні проблеми роду Hordeum L. завдяки індукуванню мутацій 3 новими ознаками роду і сімейства. Одержано новий вихідний мутантний матеріал для селекції та цінні різновидності форми і сорти ярого ячменю.

Він отримав авторське свідоцтво на винахід № 1316602 „Модифрікатори частоти індукування мутацій у рослин" та 19 авторських свідоцтв на сорти ярого ячменю (Харківський 84, Харківський 99, Субмедикум 33, Харківський 112, Екзотик, Звершення, Джерело, Бадьорий, Гама, Фенікс, Ефект, Єргенінський 2, Етикет, Аспект, Здобуток, Виклик, Парнас, Взірець, Інклюзив).

Необхідно відзначити, що 14 сучасних сортів ярого ячменю, які вирощуються в Україні, створено безпосередньо ним внаслідок проведених генетико- селекційних досліджень.

Створені М. Р. Козаченком сорти ярого ячменю мають потенціал урожайності в 6,5 9,5 т/га. їх впроваджено в зонах Лісостепу, Полісся та Степу України, а також в 4 регіонах Російської
Федерації на сотнях тисяч гектарів посівів, чим зроблено значний внесок у збільшення виробництва зерна цієї цінної сільськогосподарської культури.

Козаченко М. Р. підсумував результати проведених досліджень за 19691999 pp. у докторській дисертації „Ефрективність способів індукування і використання мутацій в селекції ярого ячменю", яку захистив у 2002 році.

Результати досліджень М. Р. Козаченка опубліковано майже в 200 наукових працях, зокрема 10 в журналах США. Вони доповідались ним на 60 наукових фрорумах, зокрема на 4 міжнародних симпозіумах КОЦ PEB.

Він нагороджений ювілейною медаллю ім. М. І. Вавилова (1987 р.), сріб- ною медаллю ВДНГ СРСР (1991р.), а також Почесними грамотами Президії УААН, Головного управління сільського господарства Харківської області й Інституту.

Значний внесок Козаченка М. Р. у підготовку наукових кадрів через аспірантуру та спеціалістів і магістрів сільського господарства.

З 2003 р. він є членом спеціалізованої вченої ради із захисту докторських та кандидатських дисертацій при Інституті рослинництва ім. В. Я. Юр'єва УААІН і при Інституті зернового господарства УААН. В 2003-2004 pр. та з 2007 р. він $€$ головою державної екзаменаційної комісії з атестації бакалаврів, спеціалістів і магістрів у Харківському національному аграрному університеті ім. В.В. Докучаева.

Редакція науково-практичного журналу „Сортовивчення та охорона прав на сорти рослин" вітає свого члена редакційної колеги з ювілеєм, сердечно бажає нових творчих досягнень, міцного здоров'я на довгі роки! 